\title{
UPAYA MENINGKATKAN SIKAP ILMIAH DAN KEMAMPUAN SISWA DALAM MEMAHAMI KOMPONEN KIMIAWI PENYUSUN SEL MELALUI METODE PERCOBAAN
}

\author{
Noneng Purmini \\ SMA Negeri 1 Kawali, Jl. Poronggol Raya No.9, Kawalimukti, Kawali, Kabupaten Ciamis, Indonesia
}

Email: nonengcmz12@gmail.com

\begin{abstract}
The purpose of this study was to determine the effectiveness of experimental methods to improve the ability to understand the chemical components of cells and to describe the learning process through experimental methods to improve the ability to understand the chemical components of cell. The participans total were 36 students of grade XI Senior High Sshool of Nature Sciience in Kawali Ciamis The research method is class action which takes place in two cycles. Each cycle consists of 4 stages, namely planning, implementing actions, observing and reflecting. The research subjects were 36 students of class XI IPA. Data collection techniques using observation and tests. Data analysis techniques using critical and interactive analysis.. The result showed that there was increasing of the percentage of students who had scored above grade standard is $100 \%$ and an increase in mastery of the material is $23.4 \%$. In addition, the experimental method has been shown to improve the behavior of students so that they are more honest, disciplined, responsible, caring, willing to work together, able to cooperate, tolerant, polite, responsive, and proactive in every activity. The conclution of this study that the experimental method can improve the ability to understand the chemical components of cell constituents
\end{abstract}

Keywords: Chemical components, cell , experiment

\begin{abstract}
ABSTRAK
Tujuan penelitian ini untuk mengetahui efektifitas metode percobaan dalam meningkatkan sikap ilmiah dan kemampuan memahami komponen kimiawi penyusun sel pada siswa kelas XI IPA di SMA Negeri 1 Kawali Ciamis.. Subyek penelitian adalah siswa kelas XI IPA berjumlah 36 orang. Metode penelitian yaitu tindakan kelas yang berlangsung dalam dua siklus. Tiap siklus terdiri dari 4 tahapan yaitu perencanaan, pelaksanaan tindakan, observasi dan refleksi. Teknik pengumpulan data menggunakan observasi dan tes. Teknik analisis data menggunakan analisis kritis dan interaktif.. Hasil penelitian menunjukkan terdapat peningkatan dalam persentase siswa kelas XI IPA 1 yang mendapat nilai di atas KKM (ketuntasan belajar) sebesar 100\% dan peningkatan penguasaan materi sebesar $23.4 \%$. selain itu, metode percobaan terbukti dapat meningkatkan sikap siswa kelas XI IPA 1 sehingga mereka lebih jujur, disiplin, tanggung jawab, peduli, mau bergotong-royong, mampu bekerjasama, toleran, santun, responsif, dan proaktif dalam setiap kegiatan. Kesimpulan penelitian ini membuktikan bahwa metode percobaan dapat meningkatkan sikap ilmiah dan kemampuan memahami komponen kimiawi penyusun sel siswa kelas XI IPA 1 SMA Negeri 1 Kawali tahun pelajaran 2019/2020
\end{abstract}

Kata Kunci: Komponen kimiawi, Penyusunan sel, percobaan

\section{PENDAHULUAN}

Kompetensi biologi mengharapkan siswa dapat menghayati dan mengamalkan perilaku jujur, disiplin, tanggung jawab, peduli (gotong royong, kerjasama, toleran, damai), santun, responsif dan proaktif dan menunjukan sikap sebagai bagian dari solusi atas berbagai permasalahan dalam berinteraksi secara efektif dengan lingkungan sosial dan alam serta dalam menempatkan diri sebagai cerminan bangsa dalam pergaulan dunia. Dalam silabus Kurikulum 2013 mata pelajaran biologi untuk kelas XI IPA semester 1 SMA Negeri 1 Kawali tahun pelajaran 2019/2020 terdapat kompetensi dasar nomor 3.1 yaitu "Memahami tentang komponen kimiawi penyusun sel, ciri hidup pada sel yang ditunjukkan oleh struktur, fungsi dan proses yang berlangsung di dalam sel sebagai unit terkecil kehidupan." Kompetensi dasar tersebut dapat dijabarkan menjadi indikator-indikator pembelajaran. Beberapa diantaranya adalah 1) Memahami struktur sel; 2) Mengetahui organelorganel sel

Namun, hasil pengamatan terhadap pembelajaran sehari-hari di kelas XI IPA 1 SMA Negeri 1 Kawali tahun pelajaran 2019/2020 menyatakan bahwa guru masih menggunakan metode 
konvensional dalam menyampaikan materi sel ini. Siswa kelas XI IPA 1 tidak diberi kesempatan untuk mencoba dan melaksanakan percobaan. Pada kondisi awal ini, siswa hanya menerima transfer informasi, pasif. Guru tidak memberikan kegiatan agar siswa mendapatkan pengalaman untuk memperkuat pengetahuannya.

Kurang berkualitasnya kinerja guru pada pra siklus mempengaruhi perilaku siswa kelas XI IPA 1 ketika proses pembelajaran memahami komponen kimiawi penyusun sel berlangsung. Dari 36 orang siswa yang ada di kelas XI IPA 1 , hanya $\leq 25 \%$ siswa saja yang responsif terhadap pertanyaan/ tugas dari guru, peduli terhadap teman sekelompok, melaksanakan gotong royong dalam kelompok, mampu bekerjasama, dan toleran terhadap perbedaan pendapat. Sedangkan pada aspek lain, hanya $26 \%$ - 50\% siswa saja yang disiplin terhadap waktu belajar, santun dalam berucap dan bertingkah laku, memiliki tanggung jawab dalam mengerjakan tugas, proaktif dalam setiap kegiatan, dan jujur dalam mengerjakan tes.

Kinerja guru dan perilaku siswa kelas XI IPA 1 yang kurang maksimal menyebabkan sebagian besar siswa kelas XI IPA 1 tidak dapat mencapai tujuan pembelajaran. Sebagian besar tidak mampu memahami komponen kimiawi penyusun sel dengan baik sehingga sebagian besar siswa mendapat nilai di bawah KKM. Dari 36 orang siswa yang ada di kelas XI IPA 1 tidak satu pun diantaranya mendapat nilai di atas KKM. Ini berarti bahwa ketuntasan belajar hanya $0.0 \%$ saja dengan tingkat penguasaan materi hanya sebesar $62.2 \%$ saja.

Dari data awal penelitian yang terkumpul dapat disimpulkan bahwa kemampuan siswa kelas XI IPA 1 dalam memahami komponen kimiawi penyusun sel masih sangat lemah. Kompetensi ini kelihatannya sangat sulit dikuasai siswa kelas XI IPA 1. Menurut hasil analisis, kekurangan pada kinerja guru dalam merencanakan dan melaksanakan pembelajaran, termasuk dalam memilih metode pembelajaran, menyebabkan perilaku siswa kelas XI IPA 1 menjadi kurang positif terhadap pembelajaran sehingga sebagian besar dari mereka mendapat nilai dibawah KKM.

Untuk mengatasi masalah di atas, peneliti memutuskan untuk memberi tindakan pembelajaran untuk meningkatkan kemampuan siswa kelas XI IPA 1 dalam memahami komponen kimiawi penyusun sel melalui metode percobaan.Tindakan yang diambil harus mampu mengatasi kendala-kendala yang ada. Tindakan ini merujuk pada beberpa hasil penelitian yang sudah dilakukan antara lain hasil penelitian Bakti Setia dkk (2013) menunjukkan bahwa(1) ada pengaruh pengunaan metode eksperimen dengan lab riil dan lab virtuil terhadap prestasi kognitif dan afektif siswa; (2) ada pengaruh kemampuan berfikir kritis terhadap prestasi kognitif dan afektif siswa; (3) ada interaksi penggunaan metode eksperimen dengan lab riil dan lab virtuil dengan kemampuan berfikir kritis terhadap prestasi kognitif dan afektif siswa .

Metode percobaan adalah cara penyampaian bahan pelajaran dengan memberikan kesempatan berlatih kepada siswa untuk meningkatkan ketrampilan sebagai penerapan bahan/pengetahuan yang telah mereka pelajari sebelumnya mencapai tujuan pengajaran Alasan pentingnya digunakan metode percobaan yaitu dapat membangkitkan motivasi belajar, dapat mengembangkan ketrampilan dasar melakukan eksperimen, dapat menjadi wahana belajar pendekatan ilmiah, dapat menunjang materi pelajaran. Selain itu percobaan dalam pelajaran biologi dapat membentuk ilustrasi bagi konsep dan prinsip biologi. Dari kegiatan-kegiatan tersebut dapat disimpulkan bahwa praktikum dapat menunjang pemahaman siswa terhadap materi pelajaran (Woolnough \& Allsop dalam Nuryani Rustaman, 2003)

Tujuan penelitian ini untuk mengetahui efektifitas metode percobaan dalam meningkatkan sikap ilmiah dan kemampuan memahami komponen kimiawi penyusun sel pada siswa kelas XI IPA di SMA Negeri 1 Kawali Ciamis..Dengan menggunakan metode percobaan, guru dapat memberi kesempatan kepada siswa melaksanakan eksperimen terkait materi sel. Selain itu, langkah-langkah metode percobaan dapat melatih perilaku siswa agar menjadi lebih positif lagi terhadap pembelajaran, disiplin, santun, responsif, tanggung jawab, peduli, mampu bergotong royong, mampu bekerjasama, toleran, proaktif, dan jujur. Diharapkan dengan meningkatnya kinerja guru dan perilaku siswa ini, siswa dapat memahami materi memahami komponen kimiawi penyusun sel dengan relatif lebih 
mudah sehingga tujuan pembelajaran dapat tercapai dengan maksimal. menjadi dasar bagi peneliti untuk melaksanakan penelitian tindakan kelas yang berjudul upaya Meningkatkan Sikap IImiah dan Kemampuan Siswa Dalam Memahami Komponen Kimiawi Penyusun Sel Melalui Metode Percobaan.

\section{METODE PENELITIAN \\ Setting dan Subyek Penelitian}

Penelitian tindakan kelas ini dilaksanakan di SMA Negeri 1 Kawali. Penelitian tindakan kelas ini dilaksanakan mulai tanggal 30 Juli 2019 sampai dengan tanggal 17 Desember 2019. Subyek dari penelitian tindakan ini adalah siswa kelas XI IPA 1 SMA Negeri 1 Kawali tahun pelajaran 2019/2020 dengan jumlah murid sebanyak 36 orang.

\section{Prosedur Penelitian Tindakan Kelas}

Prosedur penelitian mencakup tahapan-tahapan sebagai berikut: (1) perencanaan (planning); (b) penerapan tindakan (action); (c) mengobservasi dan mengevaluasi proses dan hasil tindakan (observation and evaluation); dan (d) melakukan refleksi (reflecting) dan seterusnya sampai kriteria keberhasilan yang diharapkan tercapai.

\section{Teknik Pengumpulan Data}

Dalam mengumpulkan data, peneliti dibantu oleh dua orang observer untuk memudahkan peneliti dan observer dalam mengumpulkan data, penelitian ini menggunakan lembar observasi untuk mengetahui kinerja guru dan sikap siswa ketika proses pembelajaran melalui metode experiment berlangsung, serta menggunakan lembar tes untuk mengukur kemampuan siswa dalam memahami komponen kimiawi penyusun sel.

\section{Teknik Analisis Data}

Teknik analisis data yang digunakan dalam penelitian ini adalah teknik analisis kritis dan interaktif.

\section{Indikator Keberhasilan Penelitian}

1. Meningkatnya kemampuan memahami komponen kimiawi penyusun sel siswa kelas XI IPA 1 SMA Negeri 1 Kawali tahun pelajaran 2019/2020. Indikator penelitian ini bersumber dari kurikulum 2013 dan silabus mata pelajaran biologi untuk kelas XI IPA SMA Negeri 1 Kawali tahun pelajaran 2019/2020 yang memuat Kriteria Ketuntasan Minimal (KKM) yaitu 75. Dengan kata lain, penelitian ini dapat dikatakan berhasil jika di akhir pembelajaran seluruh siswa kelas XI IPA 1 mendapat nilai di atas KKM dengan ketuntasan belajar $100 \%$.

2. Meningkatnya kualitas kinerja guru sehingga hasil observasi menunjukkan kinerja guru minimal dalam kategori baik.

3. Meningkatnya sikap siswa menjadi lebih positif terhadap pembelajaran, sehingga hasil observasi menunjukkan perilaku siswa minimal dalam kategori baik.

\section{HASIL DAN PEMBAHASAN}

Hasil

Data-data yang terkumpul dianalisis untuk mengetahui efek penerapan metode percobaan dalam meningkatkan sikap ilmiah dankemampuan memahami komponen kimiawi penyusun sel siswa kelas XI IPA 1 SMA Negeri 1 Kawali tahun pelajaran 2019/2020 .Tabel 1 dan Gambar histogram berikut memuat data hasil penelitian terkait kinerja guru. 
Tabel 1. hasil analisis terhadap kinerja guru

\begin{tabular}{llll}
\hline \multicolumn{1}{c}{ Kriteria } & \multicolumn{1}{c}{ Pra Siklus } & \multicolumn{1}{c}{ Siklus 1 } & \multicolumn{1}{c}{ Siklus 2 } \\
\hline Jumlah skor & 17 & 31 & 36 \\
Rata-rata skor & 1.42 & 2.58 & 3.00 \\
Kategori & Kurang & Baik & Baik \\
\hline
\end{tabular}

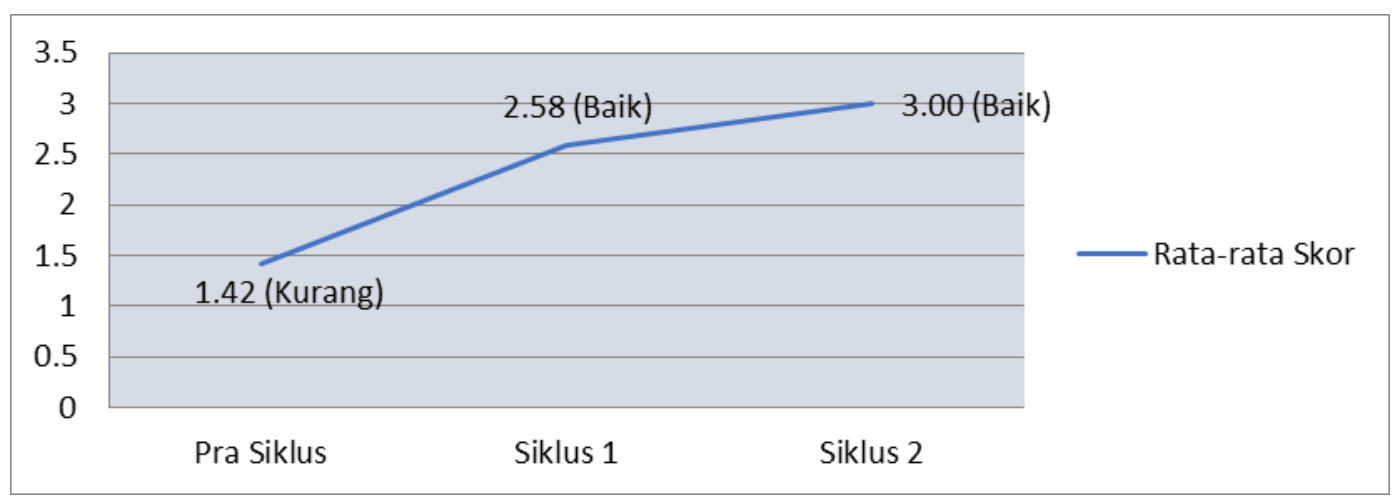

Gambar 1. histogram hasil analisis terhadap kinerja guru

Bersadarkan tabel 1 dapat diketahui bahwa ada peningkatan pada kinerja guru. Pada tindakan pra siklus rata-rata skor kinerja guru adalah 1.42 (kategori kurang). Di akhir siklus 2, ratarata skor kinerja guru meningkat menjadi 3.00 (kategori baik). Ini berarti bahwa indikator keberhasilan untuk kinerja guru telah tercapai. Tabel 2 dan gambar histogram berikut memuat data hasil penelitian terkait sikap siswa kelas XI IPA 1 ketika proses pembelajaran berlangsung.

Tabel 2. hasil analisis terhadap perilaku siswa

\begin{tabular}{llll}
\hline \multicolumn{1}{c}{ Kriteria } & \multicolumn{1}{c}{ Pra Siklus } & \multicolumn{1}{c}{ Siklus 1 } & \multicolumn{1}{c}{ Siklus 2 } \\
\hline Jumlah skor & 15 & 25 & 30 \\
Rata-rata skor & 1.50 & 2.50 & 3.00 \\
Kategori & Kurang & Cukup & Baik \\
\hline
\end{tabular}

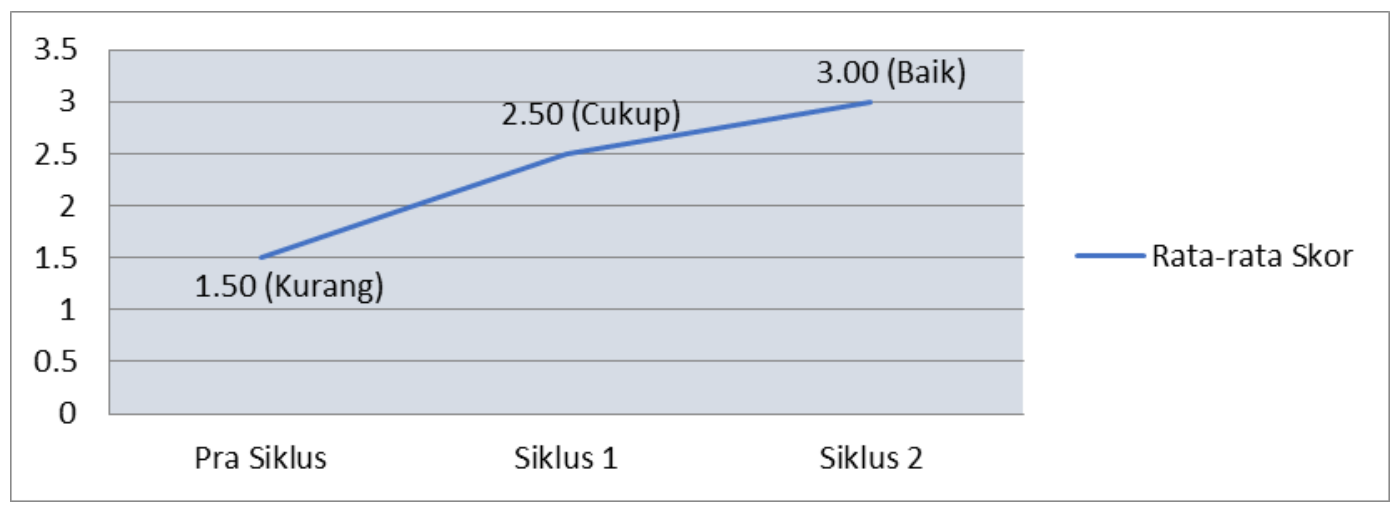

Gambar 2. histogram hasil analisis terhadap perilaku siswa

Dari tabel di atas dapat diketahui bahwa ada peningkatan pada perilaku siswa kelas XI IPA 1. Pada tindakan pra siklus rata-rata skor perilaku siswa adalah 1.50 (kategori kurang). Di akhir siklus 2, rata-rata skor perilaku siswa meningkat menjadi 3.00 (kategori baik). Ini berarti bahwa indikator keberhasilan untuk perilaku siswa telah tercapai.

Di bawah ini adalah tabel dan bagan yang memuat data hasil penelitian terkait kemampuan siswa kelas XI IPA 1 dalam memahami komponen kimiawi penyusun sel. 
Tabel 3. hasil analisis terhadap kemampuan siswa

\begin{tabular}{lccc}
\hline \multicolumn{1}{c}{ Kategori } & Pra Siklus & Siklus 1 & Siklus 2 \\
\hline Tingkat Penguasaan Materi & $62.2 \%$ & $75.4 \%$ & $85.6 \%$ \\
Ketuntasan Belajar & $0.0 \%$ & $77.8 \%$ & $100 \%$ \\
\hline
\end{tabular}

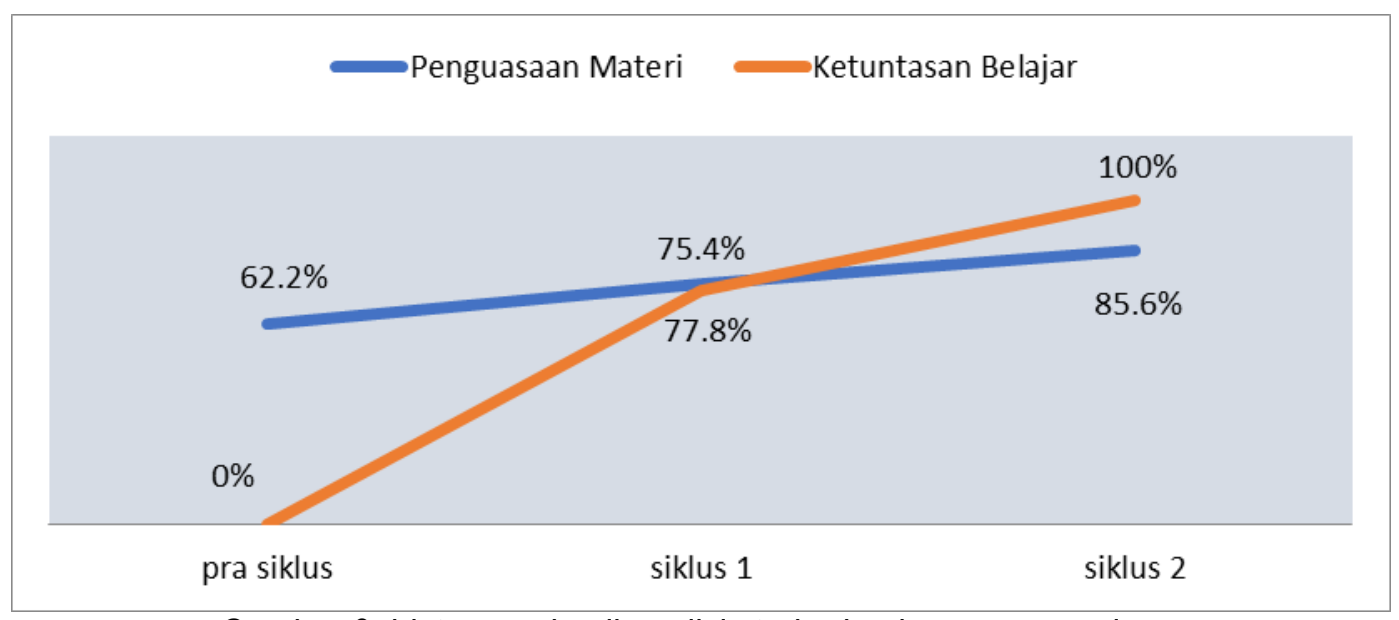

Gambar 3. histogram hasil analisis terhadap kemampuan siswa

Dari data yang dikumpulkan dari tindakan pra siklus, siklus 1, dan siklus 2, peneliti melihat adanya peningkatan dalam jumlah persentase siswa kelas XI IPA 1 yang mendapat nilai di atas KKM (ketuntasan belajar). Pada tindakan pra siklus persentasenya adalah $0.0 \%$. Pada siklus 2 , jumlahnya menjadi $100 \%$. Peneliti menghitung peningkatan jumlah siswa yang mendapat nilai di atas KKM adalah sebesar 100\%. Jadi, indikator keberhasilan penelitian ini terkait kemampuan siswa telah tercapai. Sedangkan persentase tingkat penguasaan materi pada tindakan pra siklus adalah $62.2 \%$. Di akhir siklus 2, jumlah ini meningkat menjadi $85.6 \%$. Ini berarti bahwa total peningkatan yang terjadi pada persentase penguasaan materi adalah sebesar $23.4 \%$.

Dari data-data penelitian ini dapat disimpulkan bahwa hipotesis yang menyatakan "Metode percobaan dapat meningkatkan kemampuan memahami komponen kimiawi penyusun sel siswa kelas XI IPA 1 SMA Negeri 1 Kawali tahun pelajaran 2019/2020" dapat diterima. Jadi, metode percobaan terbukti dapat meningkatkan kemampuan memahami komponen kimiawi penyusun sel siswa kelas XI IPA 1 SMA Negeri 1 Kawali tahun pelajaran 2019/2020.

\section{Pembahasan}

Kompetensi inti mata pelajaran biologi berisi perilaku jujur, disiplin, tanggung jawab, peduli (gotong royong, kerjasama, toleran, damai), santun, responsif dan proaktif dan menunjukan sikap sebagai bagian dari solusi atas berbagai permasalahan dalam berinteraksi secara efektif dengan lingkungan sosial dan alam serta dalam menempatkan diri sebagai cerminan bangsa dalam pergaulan dunia. Proses pembelajaran memahami komponen kimiawi penyusun sel melalui metode percobaan di kelas XI IPA 1 SMA Negeri 1 Kawali tahun pelajaran 2019/2020 merupakan metode pembelajaran yang ditandai dengan kegiatan mencoba mengerjakan sesuatu, mengamati dan melaporkan proses percobaan tersebut. Proses pembelajaran ini adalah cara penyajian pelajaran, dimana siswa kelas XI IPA 1 melakukan percobaan dengan mengalami dan membuktikan sendiri sesuatu yang dipelajari (Djamarah, 2006:84).

Proses pembelajaran memahami komponen kimiawi penyusun sel melalui metode percobaan di kelas XI IPA 1 SMA Negeri 1 Kawali tahun pelajaran 2019/2020 merupakan metode pembelajaran dalam bentuk pemberian kesempatan kepada siswa kelas XI IPA 1 untuk melakukan percobaan sehingga mereka mengetahui perbedaan antara sel tumbuhan dan sel hewan serta memahami struktur sel bawang (tumbuhan). Dengan metode percobaan ini, siswa kelas XI IPA 1 
sepenuhnya terlibat dalam perencanaan eksperimen, pengumpulan fakta, pengendalian variabel, dan upaya dalam masalah secara nyata. Hal ini sesuai dengan pendapat Sugihartono (2007:84) yang menyatakan bahwa metode percobaan merupakan metode pembelajaran dalam bentuk pemberian kesempatan kepada sisiwa untuk melakukan suatu proses atau percobaan. Dengan metode ini siswa diharapkan dapat sepenuhnya terlibat dalam perencanaan eksperimen, pengumpulan fakta, pengendalian variabel, dan upaya dalam masalah secara nyata.

Proses pembelajaran memahami komponen kimiawi penyusun sel melalui metode percobaan di kelas XI IPA 1 SMA Negeri 1 Kawali tahun pelajaran 2019/2020 dilakukan dengan cara mengamati, melakukan percobaan, yang di dalam penelitiannya menggunakan metode yang bersifat obyektif, baik yang dilakukan di dalam/ di luar kelas maupun di dalam laboratorium IPA. Hal ini sesuai dengan pendapat Ismail (2009:20) yang berpendapat bahwa metode eksperimen biasanya dilakukan dalam suatu pelajaran tertentu seperti ilmu alam, ilmu kimia, dan sejenisnya. Biasanya digunakan tehadap ilmu-ilmu alam yang didalam penelitiannya menggunakan metode yang bersifat obyektif, baik yang dilakukan didalam/diluar kelas maupun didalam suatu laboratorium tertentu. Sedangkan Syaodih dan Ibrahim (1996:107) berpendapat bahwa eksperimen sering dilakukan dalam pengajaran bidang studi IPA, dimana metode ini merupakan unsur pokok dalam pendekatan inquiry dan discovery (belajar dengan menemukan).

Dalam melaksanakan tindakan, peneliti terlebih dahulu menyusun sistem dan rencana pembelajaran sehingga alokasi waktu dapat efektif dan efesien karena di dalamnya terdapat kegiatan percobaan atau pengamatan yang membutuhkan waktu yang cukup banyak. Hal ini sesuai dengan pendapat Suharso (2011:129) yang berpendapat bahwa eksperimen adalah percobaan yang bersistem dan berencana (untuk membuktikan kebenaran suatu teori dan sebagainya).

Proses pembelajaran memahami komponen kimiawi penyusun sel melalui metode percobaan di kelas XI IPA 1 SMA Negeri 1 Kawali tahun pelajaran 2019/2020 dilaksanakan dengan cara penyajian pelajaran, di mana siswa kelas XI IPA 1 melakukan percobaan dengan mengalami dan membuktikan sendiri sesuatu yang di pelajari ( Djamarah BS, 1995:95). Siswa kelas XI IPA 1 melakukan percobaan untuk mengetahui perbedaan antara sel tumbuhan dan sel hewan serta memahami struktur sel bawang (tumbuhan) dengan mengalami untuk membuktikan sendiri sesuatu pertanyaan atau hipotesis yang dipelajari. Hal ini sesuai dengan pendapat Syaiful Sagala (2005:220) yang menyatakan bahwa metode percobaan adalah suatu cara mengajar, di mana siswa melakukan suatu percobaan tentang sesuatu hal, mengamati prosesnya serta menuliskan hasil percobaannya, kemudian hasil pengamatan itu disampaikan ke kelas dan dievaluasi oleh guru (Syaiful Sagala, 2005:220).

Proses pembelajaran memahami komponen kimiawi penyusun sel melalui metode percobaan di kelas XI IPA 1 SMA Negeri 1 Kawali tahun pelajaran 2019/2020 dilaksanakan dengan langkah-langkah yang disarankan oleh Sumiati (2009:102) dimana peneliti merumuskan tujuan yang jelas tentang kemampuan apa yang akan dicapai oleh peserta didik, mempersiapkan semua peralatan yang dibutuhkan, memeriksa apakah semua peralatan itu dalam keadaan berfungsi atau tidak, menetapkan langkah pelaksanaan agar efisien, memperhitungkan menetapkan alokasi waktu, memberikan penjelasan secukupnya tentang apa yang harus dilakukan dalam eksperimen, membicarakan dengan peserta didik tentang langkah-langkah yang ditempuh, variabel yang perlu diamati dan hal-hal yang perlu dicatat, menentukan langkah pokok dalam membantu peserta didik selama eksperimen, menetapkan apa tindak lanjut eksperimen (Sumiati, 2009:102), dan mengumpulkan laporan, memproses kegiatan, dan mengadakan tes untuk menguji pemahaman siswa Sanjaya (2009:151).

Dalam pelaksanaannya, proses belajar-mengajar dengan metode percobaan ini siswa kelas XI IPA 1 diberi kesempatan untuk mengalami sendiri, mengamati suatu objek, membuktikan dan menarik kesimpulan sendiri sehingga siswa kelas XI IPA 1 memperoleh pengetahuan melalui pengalaman belajar, bukan sekedar info verbal. Selain itu, pengalaman yang diperoleh siswa kelas XI IPA 1 lebih bersifat pemahaman dan bukan sekedar ingatan atau hafalan. Siswa kelas XI IPA 1 
lebih terampil untuk melakukan penyelidikan, memecahkan masalah praktis dan membuktikan asumsi teoritis. Penelitian ini membuktikan bahwa terbentuk sikap ilmiah dalam diri siswa kelas XI IPA 1 sehingga siswa mempunyai kepribadian ulet dan tangguh dalam menghadapi kehidupan di masa depan (Djamarah, 2006:84). Secara umum, perilaku siswa kelas XI IPA 1 menjadi lebih baik, jujur, disiplin, tanggung jawab, peduli, gotong royong, kerjasama, toleran, santun, responsif, dan proaktif.

\section{KESIMPULAN}

Penerapan metode percobaan sebagai upaya untuk meningkatkan sikap ilmiah dan kemampuan siswa dalam memahami komponen kimia sel efektif digunakan. Dalam pelaksanaannya, proses belajarmengajar dengan metode percobaan ini siswa mendapat kesempatan untuk mengalami sendiri, mengamati suatu objek, membuktikan dan menarik kesimpulan sendiri sehingga siswa memperoleh pengetahuan tidak verbalisme, tidak hanya menghapal tetapi dapat melatih emampuan kognitif yang levelnya lebih tinggi.melalui pengalaman belajar, bukan sekedar info verbal. Selain menentukan metode mengajar yang efektif, untuk meningkatkan kualitas proses pembelajaran seorang guru perlu mempertimbangkan beberapa hal antara lain :

1. Mengatur ruang kelas dan tempat duduk siswa sesuai dengan karakteristik dan kebutuhan siswa sehingga tercipta suasana yang nyaman dan menyenangkan untuk belajar.

2. Selalu siap membantu siswa dalam memecahkan masalah dalam belajar.

3. Memotivasi siswa untuk tetap bersemangat dalam belajar.

4. Memilih metode pembelajaran yang tepat dan efektif.

5. Memiliki sikap keterbukaan, kesediaan untuk menerima kritik dan saran terhadap kelemahankelemahan dalam proses pembelajaran.

6. Mendukung pengembangan macam-macam metode pembelajaran sebagai salah satu upaya untuk meningkatkan kemampuan siswa dalam memahami setiap materi yang dipelajari.

7. Memotivasi guru lain untuk menulis karya ilmiah seperti penelitian tindakan kelas (PTK), sebagai salah satu upaya untuk meningkatkan kredibilitas guru sebagai seorang profesional.

\section{DAFTAR PUSTAKA}

Bakti Setia , Suparmi , Sunarno W, ( 2013), Pembelajaran Biologi Melalui Metode Eksperimen Dengan Laboratorium Riil Dan Laboratorium Virtuil Ditinjau Dari Kemampuan Berfikir Kritis Dan Gaya belajar Siswa, Jurnal Inkuiri , Vol 2, No 3 p 338-246

Ismail. 2009. Strategi Pembelajaran agama Islam Berbasis Paikem. Semarang: RaSAlL Media Group.

Ibrahim. 1996. Perencanaan Pengajaran. Jakarta: Rieneka Cipta.

Rustaman, Nuryani, dkk. (2003). Strategi Belajar Mengajar Biologi, Bandung: Universitas Pendidikan Indonesia

Syaiful Bahri Djamarah. 1995. Strategi Belajar Mengajar. Banjarmasin: PT Rineka Cipta.

Syaiful Sagala. 2005. Konsep dan Makna Pembelajaran: Untuk Membantu Memecahkan Problematika Belajar dan Mengajar. Bandung: CV. Afabeta.

Djamarah. 2006. Strategi Belajar Mengajar. Jakarta: Rieneka Cipta.

Sugihartono. 2007. Psikologi Pendidikan. Yogyakarta: UNY Press.

Suharso. 2011. Kamus Besar Bahasa Indonesia. Semarang: Widya Karya.

Sumiati. 2009. Metode Pembelajaran. Bandung: Wacana Prima.

Sanjaya W. 2008. Pembelajaran dalam Implementasi Kurikulum Berbasis Kompetensi. Jakarta: Kencana Prenada Media Group. 